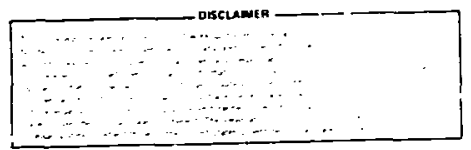

GEC'OGIC WASTE DISPOSAL AND A MODEL FOR THE SURFACE MOVEMENT

OF RADIONUCLIDFS

Jon lelton,* Ron Iman,* Jack Brown (Auburn University), Steve Sehreurs (U.S. Nuclear Regulacory Commission)

*Sandia Laboratories

Albuquerque, MM 87185

\title{
INTRODUCTION
}

In the following, a model for the surface wovement of radionuclides is presented. This model, which is referred to as the Pathways Model, was constructed at Sandia Laboratories in a profect funded by the Nuclear Regulatory Commisston to develop a methodology to assess the risk assoclated with the geologic disposal of h1gh-level radioact 1ve waste. The wethodology development Involves work in two major areas: (a) motels for physical processes, and (b) stariscical technlques for the use and assessmert of these models. The following presentation of the Pathways Model will Involve topics from bnth areas. Add1tional Information on the entire profect can be obtained from its inter im report (Campell et al., 1978)

A model for the surface movement of radionuclides in the cuntext of geologic waste disposal should permit consiciation and assessment of the many factors that may affect both radicnuclide distribution in the environment and our abllity to predict such distribution. Desirable features include the following. First, due to (a) the possible diversity of specific waste disposal sites, (b) the changes which may occur at a particular site during the loug time perlods Involved in radloactive waste disposal, and (c) the potential assessment and comparison of different sites, the model should be able to represent radionuclide movement in different physical settings. Second, the model should be able to represent radionuclide accumulation and possible reconcentrarion us well as dispersion and dilution. Third, as distribution coefficients and other factors influencing radionuclide movement are Inexactly known, the model ahould be 
amenable to gensitivicy analysis to deteroine (a) the relative Importance of Individual variables, and (b) the effects of uncertaincy in knowledge of these variables. Fourth, as poteotial release periods in radloactive waste management are lengthy, it should be possible to determine the asymptotic behavior of the model. Fifth, as rainfall and other factors influenciag radionuclide movement are functions of time (actually, stochastic processes), it should be possible to deterwine what effect: the use of average values and other simplifying assumptions has on wodel predictions.

There are many inodels for the eqviramental movement of radionuclides. Recent surveys are provided by Hof fon et al. (1977) and Strenge et al. (1976). However, after considering existing models, 1 was decided that 1t vould be nore productive to construcr a model tallored to the specific needs of the vaste disposal project chan to adapt an already extsting model to those needs. Of the existing models, the Pathuays Model has the greatest conceptual similarity जth the HERMEs godel (rletcher and Dotson, 1971).

\section{THE PATHWAYS MODEL}

For the anvironmental movement of radionuclides in the cuatext of geologic vaste disposal, there are two processes Involved with distinctly different time scales. The firct process is the long terw distribution and accumulation of radionuclides in the surface envirooment. Radionuclide release to, moverent through and removal from the eavironment wll Benerally be very siow. The second process is the movement of radionuclides from the surface environment to man. Here, the time scale is much shorter. Therefore, the Pathways Model is divided into two Bubmodels. One of these, the Environmental Transport Model, represents the loog term distribution and accumulation of radioauclides 10 the environoent. The other, the Transport to Man Model, represents the movement of radionuclides from the environment to man.

In the Environental Transport Model, radionuclide wovement is repteseated with a comartwent model. With this approach, rajlonuclides in an area under consideration are divided into a number of "comartment $s$ " and then radionuclide movement be tweec these compartments is represented by a system of linzar differenthal equations. The basic idea is to place radionuclides which are in physical regions with different characteristies in different compartments and then to determine the distribution which results from rad sunclide decay and from radionucilde movement betreen regions. 
The Environmental Transport Model uses an algorichm to construte the radionuclide transport equations described in the preceding paragraph. The basis of this algorithm is a building block called a zone. A zone corresponds to a physical region in an area to be aisdeled. Further, each zone has four bubzones (groundwater, so1l, surface vater and sediment) and varlous novements of vater and solid material assoclated with these subzones are possible. It is the wovements of vater and solid material which are assumed to be responsihle for radionuclide transport. In such wovemeats. 1t is assumed that radionuclides are partitioned between the liquid and solid phases on the basis of distribution coefflclents. A system of transport equations incorporating decay chain characteristics and regional diverelty is constructed by linking a suitable number of these zones together. In this conBtruction, exch subzone has one uniformly mixed compartwent assoclated wth it for each radionuclide in the decay chato under constderation. A siagle zone is represented in figure 1 and tho linkage of a number of zones ro represent the movement of a decay chain is represented in Figute 2.

In the Transport to Man Model, radionuclide movenent is represented by a model based on simpie food chains and concentration ratins. With this approach, food chatas whtch or iginate $1 \mathrm{n}$ an afrected area and lead to mon are decermined. Then, the radionuclide concentration in an affected food type is deterglined by the use of concentration ration, and the amount of radionuclide consumed follows from the am: is the and Comesse as currentiy employed by the Nuclear Regulitory Commission (NRC, 1977 ).

A more detailed description of the Pathways Model is provided in Chapter 4 of the project o inter in report (Campbel1 et al., 1978). Further, a user"s manual wh1ch describes the

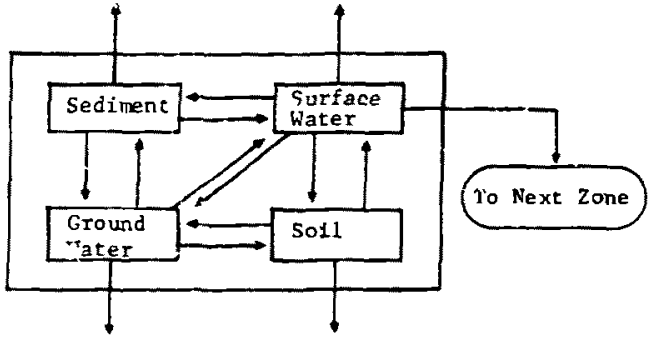

P1g, 1. Division of a zone Into Subzones. Arrows represent possible wovements of vater and solid materlal. 
Nucl 1de $1 \quad$ Nuclide 2 Nuclide $\mathrm{N}$

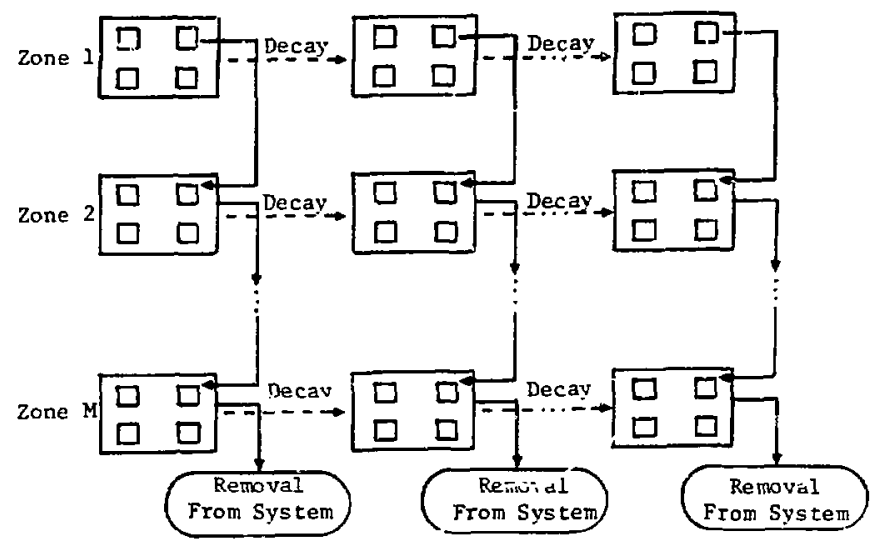

F1g. 2. Flows Associated with the Movement of a Chain of $N$ Radionuclides through a System of $M$ Zones. Figure 1 represents the flows assoclated with a single zone in greater detall.

model and the computer program which Implements it is aiso avallable (Helton and Kaestner, 1979).

It is felt that the division of the Pathways Model into the oubmodels Environmeptal Transport and Transport to Man and the construction of the Environmental Transport Model on the basis of compartments provides the capability to represent different types of radionuclide movement and also to assess both radionuclide dilution and possible reconcentration. By sultably definlag the zones and subzones assoclated wth the Eavironmental Transport Model and organizing the operation of this model in conjunction wh the Transport to Kan hodel, it is possible so represent a variety of different ad possibly diverse sites and also to represent different sets of conditions which could exist through time at a specific site. The computer program which Implements the Pathways Model is written to permit, and Indeed require, significant user involvemedt in its operation.

\section{SENS ITIVITY ANALYS IS}

For the Pathways Model, an approach to sensitivity analysis based on regression analysis has been found to be productive. The overall approach is described In Iman et al. (1979) and applications of the approach to the Environmental Transport Model are described by Helton and Iman (1979) and Helton et al. 
(1979). Basically, the idea is (a) to start wth a set of input variables wth selected ranges and distributions, (b) to select oodel Inputi fron these variables according to their ranges and distributions, (c) to generate model output wth the selected inputs, and (d) to assess the relationship between model input and output by stepwise regression. Speclal techniques found to be useful include (a) Latin hypercube sampling to select values of Input variables, (b) the rank trangform to reduce the effects of norlinearity in the relationships betueen wodel input and output, and (c) the PKESS (predicted error sum of squares) criterion to indicate overfit during regression analysis.

An exaople of a sensitivicy analysis calculation is contained in Table 1. This example 1s taken from Table 6.10 of Helton and Iman (1979) and Indicates variables affecting the bu1ldup of U234 in a flood plain. In is assumed that 2234 is entering a river and that varlous processes are acting to wove it into the flood plain. The site and the assumptions underlying 1 ts derivation are described in Helton and Iman (1979). Approxiwately 30 independent variables vere involved in the regression analysis which generated Table 1 . The following variables actually eppear in the table: B4- average soll subzone thickness, $B 7-$ a conversion factor such that the product of $B$ ? and the pore yolume of the soll subzone is equal to the snnual vater exchange between the soll subzone and the surface vater subzone, B10- a conversion factor such that the product of $B 10$ and the mass of solids contained in the soil subzone is equal to the annual solid exrhange between the boll subzope and the burface vater subzone, $B 12-$ the regional erosion rate, $B 42-$ the distr1bution coefficlent for U234 in the so11 subzone, and B43- the distribution coefficec: for $U 234$ in the surtace water subzone.

The stepwise regression analys.s which generated Table 1 vas based on raok transformed data. The first two colums indicate the variables and cross products in order as selected by the zegression analysis. The third and fourth columb coptain $R^{2}$ values based on rank transformed data and interpolations

Table 1. Stepulse Regression Results for Variables Affecting 0234 Concentration In a Flood Plain.

\begin{tabular}{|c|c|c|c|c|}
\hline Step & Variable & Rank $\mathrm{R}^{2}$ & Raw $\mathrm{R}^{2}$ & St. Reg. C. \\
\hline 1 & B43 & 0.614 & 0.368 & 0.745 \\
\hline 2 & B 42 & 0.796 & 0.665 & 1.283 \\
\hline 3 & B $42 \star B 42$ & 0.849 & 0.669 & -0.866 \\
\hline 4 & $\mathrm{~B} 10 \star_{B} 43$ & 0.878 & 0.702 & 0.254 \\
\hline 5 & $\mathrm{~B} 12 \star \mathrm{B} 43$ & 0.901 & 0.812 & -0.189 \\
\hline 6 & $B 4 \star B 7$ & 0.914 & 0.835 & 0.118 \\
\hline
\end{tabular}


from rank transformed data to raw (1.e., unzransformed) data, respectively. The Rank $\mathrm{R}^{2}$ indicates how successful the regresston model is in predicting the relative importance of variables In Influencing the Environmental Transport Hodel while the Raw $\mathrm{R}^{2}$ indicates how auccessful the regression model is in duplicating the Environmental Transport Model. The fifth colum contains standaidized regression coefficlents for the individual variables in the regression model at the last step of the ragression analysis. The absolute value of these coefficlents provides a ranking of the relative importance of the individual variables in 1pflueacing the model. Many regression analyses of the form indicated here are presented in Helton and Iman (1979) and Helton et al. (1979).

\section{ASYMPTOT IC BEHAVIOR}

It is possible to show that, for a fixed rate of radionuclide input, the radionuclide concentrations as predicted by the Environmental Transnort Model will Increase monotonically to asymptotic limits. is the time required in many situations to reach steady state in the surface environment may be short relative co other processes involved in the release of radicnuclides to the surface enviroament (1.e., groundwater trans$p(L t)$, It may be desirable to use asymptotic values for radioc:clide concentrations in the surface environment rather than calculating and using their values as functions of time. For the same zone and varlables used in the generation of Table 1, the varlation in $t$ lme to 90 percent steady state and concentration at steady state for an assumed 1nput rate of 1 atom/yr of Cm245 to the surface water aubzone is represented in Table 2. This table is adapted from Tables 4.4 through 4.7 of Helton et al. (1979); this report contains numerous such complations as well as sensitivity analyses similar to the one presented in Table 1 for the varlables influenclag t1me to 90 percent steady state and concentration at steady state. As the Environmental Transport Model is IInear wth respect to radionuclide input, such calculations can be scaled to represent other input rates.

\section{TIME VARYING PARAYETERS}

In the Environmental Transport Model, as will probably be the case for any model used to represent the surface movement of radionuclides, many parameters are based on "averaged" water and solid flow rates. Of ten, mean annual flow rates are used whereas the flow rates are (at best) perlodic functions or (more realistically) perlodic stochastic processes. It is desirable to assess the effect that the replacement of parameters wh their average values has on model predictions. Such a study has been Initiated for the Environmental Transport Model (Brow and Helton, 1979). 
Tab1e 2. Time to 90 Percent Steady State and Concentration at Steady State for an Asssumed Input co the Surface Hater Subzone of 1 atom/yr of Cm245. Time $1 \mathrm{~g}$ In years; surface vater concentration is in atoms/L; all other concentrations are In acoms/kg.

\begin{tabular}{|c|c|c|c|c|c|}
\hline & & $\begin{array}{l}\text { Ground } \\
\text { Water }\end{array}$ & Soll & $\begin{array}{c}\text { Surface } \\
\text { Water } \\
\end{array}$ & $\begin{array}{l}\text { Sed } 1- \\
\text { ment }\end{array}$ \\
\hline T lae to & Min Imum & $.10 E+03$ & $.10 E+02$ & $.10 E+01$ & $.10 \mathrm{E}+02$ \\
\hline 907 & Maximum & $.28 E+05$ & $.51 E+04$ & $.27 E+03$ & $.44 E+03$ \\
\hline Steady & Average & $.11 E+05$ & $.34 \mathrm{E}+03$ & $.20 \mathrm{E}+02$ & $.72 \mathrm{E}+02$ \\
\hline State & St. Dev. & $.10 \mathrm{E}+05$ & $.43 E+03$ & $.33 E+02$ & $.65 E+02$ \\
\hline $\begin{array}{l}\text { Conc. at } \\
\text { Steady } \\
\text { Stace }\end{array}$ & $\begin{array}{l}\text { Man Imum } \\
\text { Maximum } \\
\text { Average } \\
\text { St. Dev. }\end{array}$ & $\begin{array}{l}.12 \mathrm{E}-16 \\
.13 \mathrm{E}-09 \\
.30 \mathrm{E}-11 \\
.11 \mathrm{E}-10\end{array}$ & $\begin{array}{l}.14 \mathrm{E}-13 \\
.38 \mathrm{E}-09 \\
.37 \mathrm{E}-10 \\
.58 \mathrm{E}-10\end{array}$ & $\begin{array}{l}.35 \mathrm{E}-13 \\
.94 \mathrm{E}-13 \\
.54 \mathrm{E}-13 \\
.14 \mathrm{E}-13\end{array}$ & $\begin{array}{l}.42 E-12 \\
.45 E-09 \\
.75 E-10 \\
.87 E-10\end{array}$ \\
\hline
\end{tabular}

That study investigates the effects of multiplying the coefficient matr $1 x$ for the radionuclide transport equations by a periodic function and by a perlodic stochastic process. The function and the stochastic process vere plcked to mimic observed hydrologic patcerns. Fol: the perlodic hydrologic process, it was possible to calcuiate bounds on the difference between predictions made with the untrangformed and trangformed coefficlent matrix; for the stochastic hydrologic process, there was less success at obtaining analytic agsesments of the untrensformed and transformed cases and computer sinulations Were used to obtain an indication of their differences. Overall, the varlation was not large between concentrations calculated with averaged yearly values and vith elther periodic or periodic stochast1c perturbations of these values. Th1s is especially true as the uncertainty in some of the other parameters which are used as model input (particularly distribution coefficlents) can produce much larger variation in model predictions.

\section{REFERENCES}

Brow, J. B., and Helton, J. C., 1979, "Risk Methodology for Geologic Disposal of Radloactive Haste: Effects of Varlable Hydrolog1c Patterns on the Environmenta] Transport Model," Report No. SAND79-1909, Sandia Laboratorles, Albuquerque, NM. Campbell, J. E., Dillon, R. T., THeraey, M. S., Davis, H. T., McGrath, P. E., Pearbon, F. J., Shaw, H. R., Helton, J. C., and Donath, F. A., 1978, "R1sk Hethodology For Geologic Dispasal of Radioact Ive Waste: Interim Report," Report No. SAND 78-0029, Sand1a Laboratorles, Albuquerque, NM. 
Fletcher, J. F., and Dotson, W. L. (Comp1lers), 1971, "HERMES A Digital Computer Code for Est Imating Reglonal Radiologica! Effects from the Nuclear Power Industry," Report No. HEDL-TME71-168, Hanford Erglneering Development Laboratory, Richland, WA.

Helcon, J. C., Brown, J. B., and Iman, R. L., 1979, "Risk Methodology for Geologic Disposal of Radioactive Waste: Asymptotic Properties of the Environmental Transport Madel," Report No. SAND79-1908, Sandia Latorator les, Albuquerque, NM. Helton, J. C., and Iman, R. L., 1979, "RIsk Methodology for Geologic Disposal of Radlaactive Waste: Sensitivity Analysis of Pathways Model," Report No. SAND79-1393, Sandia Laberatorles, Albuquerque, NM.

Helton, J. C., and Kaestner, P. C., 1979, "R1sk Methudology Eor Geologic Disposal of Radioactive Waste: User Manual for Pathways Model," Report No. SAND7B-1711, Sandia Laboratories, Albuquerque, NM.

Hoffman, F. 0., Mlller, C. W., Shaeffer, D. L., and Garten, C. T., 1977. "Computer Codes for the Assessment of Radionuclides

Released to the Environment," Nuclear Safety 18, pp. 343-354.

Iman, R. L., Helcon, J. C., and Campbel1, J. E., 1978, "Risk Methodology for Geologic Disposal of Radloactive Waste: Sensitivity Analysis Techniques," Report No. SAND78-0912, Sandia Laìontatorles, Albuquerque, NM.

Strenge, D. L., Watson, E. A., and Droppo, J. G., 1976, "Review of Calculational Models and Computer Codes for Environmental Dose Assessment of Radioactive Releases," Report No. BNHL-B-454, Battelle Pacffic Nortíwest Laboratories, Richland, WA.

U.S. Nuclear Regulatory Ccmmission, 1977, "Calculation of Annual Doses to Man from Routine Releases of Reactor Ef fluents for the Purpose of Evaluat1ng Compliance with 10 CFK Part 50, Appendix I," Regulatory Guide 1.109, Revision 1. 